\title{
PENGEMBANGAN MASYARAKAT SEBAGAI KONSEP DAKWAH
}

\author{
P-ISSN: 2085-4536 | E-ISSN: 2721-7183 \\ Link: https://jurnal-stidnatsir.ac.id/index.php/binaummat/article/view/49 \\ DOI : https://doi.org/10.38214/jurnalbinaummatstidnatsir.v2i02.49 \\ Dikirim: 25-03-2019 \\ Direview: 05-04-2019 \\ Diterbitkan: 17-04-2019 \\ LUKMAN \\ lukman@stidnatsir.ac.id \\ STID Mohammad Natsir - Indonesia
}

\begin{abstract}
ABSTRAK
Tujuan Penelitian: Untuk mengetahui pengembangan masyarakat sebagai konsep dakwah. Metode Penelitian: Kualitatif. Hasil Penelitian: Bagi masyarakat Muslim, pengembangan masyarakat dan dakwah adalah dua hal tidak dapat dipisahkan, karena pada dasarnya masyarakat dalam Islam lahir dari sebuah gerakan dakwah. Meskipun dunia modern saat ini telah banyak mengembangkan teori-teori pengembangan masyarakat, namun teori-teori dan strategi tersebut telah diaplikasikan dalam gerakan dakwah Islam. Inilah yang coba diuraikan dalam tulisan singkat ini, yaitu bagaimana sebuah gerakan dakwah melahirkan sebuah masyarakat yang berbudaya dan berperdaban tinggi, sebagaimana yang telah dicontohkan oleh Rasulullah SAW dalam dakwahnya yang kemudian melahirkan sebuah masyarakat yang islami dan modern. Hasil dari tulisan ini membuktikan bahwa dakwah yang dilakukan seorang da'i sesungguhnya adalah gerakan pengembangan masyarakat. Karena tujuan dari sebuah gerakan dakwah adalah untuk mengangkat derajarat dan martabat seseorang atau masyarakat kepada yang lebih tinggi, baik dalam ekonominya, budaya maupun pendidikannya. Menjadikan masyarakat adil dan sejahtra, berbudaya dan berperadaban tinggi.
\end{abstract}

Kata Kunci: pengembangan masyarakat, konsep dakwah

\section{PENDAHULUAN}

Pengembangan masyarakat (community development) adalah kegiatan pengembangan masyarakat yang dilakukan secara sistimatis, terencana dan diarahkan untuk memperbesar akses masyarakat guna mencapai kondisi 
sosial, ekonomi dan kualitas kehidupan yang lebih baik apabila dibandingkan dengan kegiatan pembangunan sebelumnya. ${ }^{1}$

Sedangkan dakwah adalah upaya mengaktualisasikan nilai-nilai dan ajaran Islam ke dalam kehidupan masyarakat sehingga terwujud masyarakat yang sejahtra dunia dan akhirat. Dengan demikian dakwah merupakan proses pembinaan masyarakat baik dilakukan secara invidu maupun kelompok dengan metode dan strategi yang terencana dan terukur dengan baik. Karena untuk mencapai tujuan dari dakwa itu sendiri diperlukan langkah-langkah yang terprogram, seperti bagaimana mencapai tujuan, langkah-langkah praktis menuju tujuan dan evaluasi.

Jika kita melihat bahwa Pengembangan masyarakat (community development) merupakan salah satu upaya untuk menolong anggota masyarakat yang sedang menghadapi beragam permasalahan dalam pencapaian taraf hidup layak dan berkualitas. Maka demikian pula dengan dakwah yaitu untuk mensejahtrakan, meningkatkan taraf hidup masyarakat baik secara invidu maupun sosial, selamat dunia dan akhirat. Sehingga dapat disimpulkan bahwa pengembangan dan pembangunan masyarakat adalah proses dari serangakaian kegiatan dakwah yang mengarah pada peningkatan tarap hidup dan kesejahteraan masyarakat. Berdasarkan pemahaman tersebut, dakwah adalah sebuah praksis, dakwah dituntut untuk mampu memberikan perubahan kepada masyarakat. Perubahan tersebut bisa berupa kualitas maupun kuantitas dalam kehidupan bermasyarakat. Perubahan yang menyangkut kualitas, berkaitan dengan tuntutan perubahan masyarakat dari masyarakat yang belum maju menjadi masyarakat yang lebih maju, dari masyarakat yang maju bagaimana menjadi masayarakat yang lebih maju. Oleh karena itu dakwah pada dasarnya tidak mendukung adanya (status quo) dalam masyarakat, karena salah satu tujuan dari dakwah adalah bagaimana memfungsikan agama dalam masyarakat secara maksimal. Perubahan dari segi kuantitas, berkaitan dengan

\footnotetext{
1 Akmaruzzaman , Sumardjo, dan Himawan Hariyoga, Strategi Mensinergikan Program Pengembangan Masyarakat Dengan Program Pembangunan Daerah, dalam Jurnal Manajemen Pembangunan Daerah, Vol. 5 No. 1, Juni 2013, hlm. 50
} 
bertambahnya jumlah pemeluk agama, tempat-tampat ibadah dan saranasarana sosial keagamaan dalam masyarakat. ${ }^{2}$

Bahkan apabila melihat pada asal muasal lahirnya sebuah masyarakat dalam Islam, tidak bisa dipisahkan dengan dakwah. Nabi Muhammad SAW membentuk masyarakat Yatsrib menjadi masyarakat Madinah yang berperadaban dan berbudaya tinggi adalah melalui proses dakwah yang panjang, yang beliau mulai Rasulullah sejak di Mekkah hingga hijrah ke Madniah dalam kurun waktu 23 tahun.

\section{Pengembangan Masyarakat}

Secara etimologi, Pengembangan Masyarakat atau community development terdiri dari dua kata, yaitu "pengembangan" dan "masyarakat". Pengembangan atau pembangunan memiliki makna usaha bersama dan terencana untuk meningkatkan kualitas kehidupan manusia. Bidang-bidang pembangunan biasanya meliputi beberapa sektor, yaitu ekonomi, pendidikan, kesehatan dan sosial-budaya.

Secara terminologi, istilah pengembangan masyarakat dalam Kamus Bahasa Indonesia diartikan sebagai usaha bersama yang dilakukan oleh penduduk atau masyarakat untuk memenuhi kebutuhannya. Pengembangan masyarakat juga dapat diartikan sebagai sebuah proses penyadaran dan penggalian potensi lokal masyarakat dengan tujuan untuk memecahkan permasalahan mereka sehari-hari. ${ }^{3}$

Jadi pengembangan masyarakat adalah komitmen dalam memberdayakan masyarakat lapis bawah sehingga mereka memiliki berbagai pilihan nyata menyangkut masa depannya. Kegiatan pengembangan masyarakat difokuskan pada upaya menolong orang-orang lemah yang memiliki minat untuk bekerja samadalam kelompok, melakukan identifikasi terhadap kebutuhan dan melakukan kegiatan bersama untuk memenuhi kebutuhan mereka. ${ }^{4}$

${ }^{2}$ Agus Riyadi, Formulasi Model Dakwah Pengembangan Masyarakat Islam, dalam Jurnal An-Nida, Vol. 6, No. 2, 2014, hlm. 112

3 Erna, Definisi Pengembangan Masyarakat, Pendekatan Radikal Dan Pendekatan Profesional. Dalam https://www.academia.edu/18834900/DEFINISI_PENGEMBANGAN_MASYARAKA T_PENDEKATAN_RADIKAL DAN_PENDEKATAN_PROFESIONALI

4 Zubaedi, Pengembangan Masyarakat: Wacana dan Praktik, Jakarta: Kencana, 2016, hlm. 4 
PBB mendefinisikan pengembangan masyarakat (community development) : "community development is the processes by which the efforts of the peoplethemselves are united with those of governmental authorities to improve the economic, social and cultural conditions of communities, to integrate the communities into the life of the natio, and to enhance the contribute fully to national progress." ${ }^{5}$

Adapun definisi dari pengembangan atau pembangunan masyarakat (community development) menurut para ahli sebagai berikut :

1. Menurut Wuradji sebagaimana dikutip oleh Abdul Rahmat, pengembangan masyarakat merupakan proses pembangunan kesadaran kritis yang dilakukan secara transformatif, partisipatif, sistematis dan berkesinambungan melalui pengorganisasian dan peningkatan kemampuan menangani berbagai persoalan dasar yang mereka hadapi untuk mengarah pada perubahan kondisi hidup yang semakin baik sesuai dengan cita -cita yang diharapkan. Jadi yang dimaksud dengan istilah pengembangan masyarakat dalam studi ini adalah proses penyadaran dan penggalian potensi lokal masyarakat yang dilakukan oleh seluruh komponen masyarakat secara bersama-sama, dengan tujuan memenuhi kebutuhan serta mencari solusi atas permasalahan yang dihadapi oleh mereka.

2. Sedang menurut Twelvetrees, pengembangan masyarakat adalah "the process of assisting ordinary people to improve their own communities by undertaking collective actions". Secara khusus pengembangan masyarakat berkenaan dengan upaya pemenuhan kebutuhan orang-orang yang tidak beruntung atau tertindas, baik yang disebabkan oleh kemiskinan maupun oleh diskriminasi berdasarkan kelas sosial, suku, jender, jenis kelamin, usia, dan kecacatan. ${ }^{6}$

3. Siagian (1994) memberikan pengertian tentang pembangunan sebagai "Suatu usaha atau rangkaian usaha pertumbuhan dan perubahan yang berencana dan dilakukan secara sadar oleh suatu bangsa, negara dan pemerintah, menuju modernitas dalam rangka pembinaan bangsa (nation building)".

${ }^{5}$ Fredian Tonny Nasdian, Pengembangan Masyarakat, Jakarta: Yayasan Pustaka Obor Indonesia, 2014,hlm. 31

6 Zubaedi, Pengembangan Masyarakat: Wacana dan Praktik, Jakarta: Kencana, 2016, hlm. 5 
4. Ginanjar Kartasasmita (1994) memberikan pengertian yang lebih sederhana, yaitu sebagai "suatu proses perubahan ke arah yang lebih baik melalui upaya yang dilakukan secara terencana".

5. Alexander (1994) mendefinisikan pembangunan (development) sebagai proses perubahan yang mencakup seluruh system sosial, seperti politik, ekonomi, infrastruktur, pertahanan, pendidikan dan teknologi, kelembagaan, dan budaya.

6. Brokensha dan Hodge, Community development is a movement designed to promote better living for the whole community with the active participation and on the initiative of the community. (Pengembangan masyarakat adalah suatu gerakan yang dirancang guna meningkatkan taraf hidup keseluruhan masyarakat melalui partisipasi aktif dan inisiatif dari masyarakat). Definisi tersebut memberikan gambaran tentang upaya untuk meningkatkan kemampuan masyarakat serta berusaha menciptakan suatu kondisi yang memancing kemauan dan insiatif sendiri dari masyarakat yang bersangkutan. Dengan adanya peningkatan kemampuan dan inisiatif mereka, diharapkan masyarakat semakin mandiri dan mampu memahami permasalahan yang dihadapi serta potensi yang mereka miliki untuk dimanfaatkan semaksimal mungkin.

7. Dunham mengatakan pengembangan masyarakat merupakan "Organized efforts to improve the conditions of community life, primarily through the enlistment of self-help and cooperative effort from the villagers, but with technical assistance from government or voluntary organizations". (berbagai upaya yang terorganisir yang dilakukan guna meningkatkan kondisi kehidupan masyarakat, terutama melalui usaha yang kooperatif dan mengembangkan kemandirian dari masyarakat pedesaan, tetapi hal tersebut dilakukan dengan bantuan teknis dari pemerintah ataupun lembaga-lembaga sukarela). ${ }^{7}$

\section{Pinsip-Prinsip Pengembangan Masyarakat}

${ }^{7}$ Erna, Definisi Pengembangan Masyarakat, Pendekatan Radikal Dan Pendekatan Profesional. 
Prinsip adalah suatu pernyataan tentang kebijakan yang dijadikan pedoman dalam pengambilan keputusan dan melaksanakan kegiatan secara konsisten. Karena itu prinsip berlaku umum dan diterima secara umum. Dengan demikian "prinsip" dapat dijadikan sebagai landasan pokok yang benar,bagi pelaksanaan kegiatan yang akan dilakukan. ${ }^{8}$

Pembahasan tentang prinsip pengembangan masyarakat sudah banyak dilakukan para ahli, seperti M. Djauzi menyebutkan 6 prinsipprinsip pengembangan masyarakat:

1. Partisipasi dalam pembuatan keputusan yang bebas dan terbuka

2. Penggambaran secara ringkas keadaan masa yang akan dating

3. Penggunaan metode ilmiah

4. Pencapaian pengertian dan consensus

5. Setiap orang mempunyai hak untuk didengarkan pendapatnya.

6. Semua orang boleh berpartisipasi. ${ }^{9}$

Adapaun prinsip-prinsip pengembangan masyarakat dalam perspektif Jim Ife ada 22 prinsip, dimana satu sama lain saling berkaitan:

1. Pembangunan Terpadu (integrated development). Pembangunan sosial, ekonomi, budaya,lingkungan hidup, kepribadian dan spiritual merupakan aspek penting dalam kehidupan masyarakat. Aspek- aspek ini harus dikembangkan dan saling mendorong satu sama lain. Misalnya program pengembangan masyarakat yang berkonsentrasi pada aspek ekonomi juga sangat mungkin digunakan untuk mendorong kegiatan menuju tercapainya aspek budaya dan pelayanan masyarakat lainnya.

2. Melawan kerugian structural (confronting structural disadvantage). Struktu kelas, gender dan keragaman etnik sering menjadi kendala dalam pengembangan masyarakat. Pengembangan masyarakat harus merancang bekerjasama dalam mengatasi kerugian yang ditimbulakn oleh factor kelas, gender, ras/etnik, umur, ketidak mampuan dan jenis kelamin.

3. Hak asasi manusia (buman rights). Pemahaman dan komitmen terhadap hak asasi manusia merupakan prinsip yang penting dalam pengembangan masyarakat.

8 Totok Mardikanto dan Poerwoko Soebiato, Pemberdayaan Masyarakat dalam Perspektif Kebijakan Publik, Bandung: Alfabeta, 2019, hlm. 105

${ }^{9}$ M. Djauzi Moedzakir, Teori \& Praktek Pengembangan Masyarakat Suatu Pedoman Bagi Para Praktisi, Surabaya: Usaha Nasional, 1986, hlm. 26 
4. Keberlanjutan (sustainability). Prinsip keberlanjutan merupakan salah satu komponen penting dalam pendekatan ekologis.

5. Pemberdayaan (empowerment). Pemberdayaan mempunyai makna dalam menyediakan sumberdaya, peluang, pengetahuan dan keahlian masyarakat untuk meningkatkan kapasitas atau kemampuannya dalam menentukan masa depannya dan berpartisipasi dalam kehidupan bermasyarakat.

6. Personal dan politik (the personal and the politica). Kaitan antara person dan politik, individu dan struktur, masalah pribadi dan isu publik merupakan unsur pokok dalam pengembangan masyarakat.

7. Kepemilikan masyarakat (community ownership). Kepemilikan mencakup kepemilikan atas barang dan kepemilikan atas struktur dan proses.

8. Kepercayaan diri (self reliance). Masyarakat harus mencari pemanfaatan sumberdaya yang dimilikinya, jangan lebih tergantung pada dukungan dari luar yang berupa bantuan finansial, teknis, maupun sumberdaya lain.

9. Kemandirian (independence from the state). Bantuan pemerintah dalam pembangunan masyarakat sudah berjalan cukup lama.

10. Tujuan jangka menengah dan visi yang jelas (immediate goals and ultimate visions).

11. Pengembangan organik (organic development). Pemikiran pengembangan organik sering dipertentangkan dengan pengembangan mekanistik, pengembangan mekanistik ibarat sebuah mesin, sedangkan pengembangan organik ibarat sebuah tanaman.

12. Pengembangan bertahap (the pace of development). Sebagai konsekuensi alamiah dalam pengembangan organik adalah perlunya penetapan langkah dalam mengadakan pengembangan masyarakat.

13. Keahlian eksternal (external expertise). Proses atau struktur yang datang dari luar dalam pengembangan masyarakat jarang bekerja secara baik.

14. Pembangunan komunitas (community building). Semua pengembangan masyarakat harus bertujuan membangun komunitasnya. 
15. Proses dan hasil (process and outcome). Penekanan dalam proses dan hasil menjadi isu penting dalam pekerjaan masyarakat.

16. Keutuhan (keterpaduan) proses (the integrity of process). Proses yang digunakan dalam pengembangan masyarakat sama pentingnya dengan hasil.

17. Tanpa kekerasan (non violence). Dalam konteks ini, tanpa kekerasan mempunyai implikasi lebih dari sekedar tanpa kekerasan fisik diantara penduduk.

18. Inklusif (inclusiveness). Prinsip ini merupakan bagian dari prinsip tanpa kekerasan.

19. Konsensus (consensus). Prinsip tanpa kekerasan, dan inklusifness harus dibangun dalam kerangka pembentukan konsensus, dan konsensus dalam pengambilan keputusan harus diterapkan sebisa mungkin.

20. Kerjasama (co-operation). Perspektif ekologis dan pendekatan tanpa kekerasan menekankan kebutuhan struktur kerjasama dibanding struktur persaingan.

21. Partisipasi (participation). Pengembangan masyarakat bertujuan tercapainya partisipasi yang maksimal, yakni melibatkan semua anggota masyarakat dalam semua kegiatan dan semua proses yang terjadi dalam masyarakat.

22. Pembatasan (perumusan) kebutuhan (defining need). Pertama, pengembangan masyarakat harus mampu menemukan kesepakatan diantara berbagai variasi kebutuhan masyarakat. ${ }^{10}$

\section{Strategi Pengembangan Masyarakat}

Menurut FM Loewenberg, strategi bukanlah statement yang bersifat menggeneralisir bisa digunakan oleh siapa saja dalam menghadapi persoalan apa saja. Strategi yang dipakai sangat ditentukan oleh tujuan apa yang hendak dicapai, serta kondisi apa yang tercipta. Strategi yang dipakai dalam memecahkan perseolan tertentu akan sangat berbeda dengan strategi yang diterapkan untuk memecahkan masalah yang lain pula. Pengembangan strategi sangat didasarkan pada asumsi-asumsi

${ }^{10}$ Sumaryo Gitosaputro dan Kordiyana K. Rangga, Pengembangan dan Pemberdayaan Masyarakat, Konsep, Teori dan Aplikasinya di EraOtonomi Daerah, Yogyakarta: Graha Ilmu, 2015, hlm. 19-26 
perencanaan yang rasional dan dibutuhkan bagi pemecahan masalah yang ada. $^{11}$

Adapun fungsi strategis pengembangan masyarakat menurut Suharto ialah:

1. Memberikan pelayanan sosial yang berbasis masyarakat mulai dari pelayanan preventif untuk anak-anak sampai pelayanan kuratif dan pengembangan untuk keluarga yang berpendapatan rendah.

2. Menolong anggota masyarakat yang memiliki kesamaan minat untuk bekerjasama, mengidentifikasi kebutuhan bersama dan kemudian melakukan kegiatan bersama untuk memenuhi kebutuhan tersebut.

3. Memenuhi kebutuhan orang-orang yang tidak beruntung atau tertindas, baik yang disebabkan oleh kemiskinan maupun oleh diskriminasi berdasarkan kelas sosial, suku, gender, jenis kelamin, usia, dan kecacatan. ${ }^{12}$

Berikut beberapa padangan para ahli tentang strategi pengembangan masyarakat:

1. Chin dan Benne, menurutnya dalam pengembangan masyarakat ada 3 strategi yang digunakan yaitu:

a. Strategi ratonal-empirical (Empiris-Rasional), yaitu pengembangan masyarakat yang dilakukan berdasarkan fakta-fakta yang ada di dalam masyarakat.

b. Startegi normative-reducative (Normatif-redukatif), yaitu untuk mengubah sikap, perasaan dengan asumsi perilaku masyarakat karena didukung oleh norma soaial budaya, agama.

c. Strategi power-coorcive, terkait dengan masalah ketimpangan kekuasaan dalam masyarakat. ${ }^{13}$

\footnotetext{
${ }^{11}$ Nani Machendrawaty dan Agus ahmad Safei, Pengembangan Masyarakat islam, Bandung: Rosda, 2001, hlm. 97

${ }^{12}$ Ahmad Zaini, Peranan Dakwah dalam Pengembangan Masyarakat Islam, dalam Jurnal Community Development, Volume 1, Nomor 1, Juni 2016, hlm. 144

${ }^{13}$ Fredian Tonny Nasdian, Pengembangan Masyarakat, hlm. 60
} 
2. Morris dan Binstock juga memperkenalkan tiga strategi perencanaan pengemangan masyarakat:

a. Modifikasi pola sikap dan perilaku dengan pendidikan dan aksi lainnya.

b. Mengubah kondisi social dengan mengubah kebisajakankebisakan organisasi formal;

c. Reformasi peraturan dan system fungsional suatu masyarakat. ${ }^{14}$

3. Ismawan menetapkan ada 5 strategi pengembangan masyarakat, yaitu:
a. Pengembangan sumberdaya manusia;
b. Pengembangan kelembagaan kelompok;
c. Pemupukan modal masyarakat;
d. Pengembangan usaha produktif;
e. Penyediaan informasi tepat-guna.

4. Suharto, dalam penelaahannya terhadap strategi pemberdayaanmasyarakat, ia mengemukakan 5 aspek penting yang dapat dilakukan dalam melakukan pemberdayaan masyarakat:

a. Motivasi, setiap warga didorong untuk membentuk kelompok yang merupakan mekanisme kelembagaanuntuk mengorganisir dan melaksankan pengembangan masyarakat.

b. Peningkatan kesadaran dan pelatihan kemampuan.

Peningkatan kesadaran masyarakat dapat dicapai melalui pendidikan dasar, perbaikan kesehatan, imunisasi dan sanitasi. Sedangkan keterampilan diperoleh melalui caracara partisipatif.

${ }^{14}$ Ibid. 
c. Manajemen diri, pada tahap awal pendamping dari luar dapat membantu mereka dalam mengembangkan sebuah system.

d. Mobilisasi sumberdaya, diperlukan pengembangan metode untuk menghimpun sumber-sumber individual melalui tabungan regular dan sumbangan sukarela dengan tujuan menciptakan modal social.

e. Pembangunan dan pengembangan jaringan. ${ }^{15}$

5. Marnia Nes, dalam Modul Review Pelaksanaan Siklus PNPM Mandiri Perkotaan, Jakarta: Direktorat Jenderal Cipta Karya Departemen Pekerjaan Umum, 2008. Menyebutkan Ada tiga strategi utama pemberdayaan dalam praktek perubahan sosial, yaitu:

a. Strategi tradisional, menekankan pada kebebasan dalam memilih kepentingan dengan sebaik-baiknya dalam berbagai keadaan.

b. Strategi direct action atau tindakan langsung, yaitu dimunculkannya dominasi kepentingan yang dihormati oleh semua pihak yang terlibat dan mempunyai peluang yang besar untuk terjadinya perubahan.

c. Strategi pemberdayaan transformatif yaitu pemberdayaan yang berbasis pendidikan masyarakat secara paritisipatif yang menekankan kesadaran-kesadaran kritis untuk menjunjung nilai-nilai kebersamaan dan hubungan yang mutualistik. ${ }^{16}$

6. Tjahya Supriyatna yang dikutip A.Halim menyebutkan bahwa secara umum, ada empat pengembangan masyarakat, yaitu:

\section{a. The Growth Strategy}

Penerapan strategi pertumbuhan ini pada umumnya dimaksudkan untuk mencapai peningkatan yang cepat

15 Totok Mardikanto dan Poerwoko Soebiato, Pemberdayaan Masyarakat dalam Perspektif Kebijakan Publik...., hlm. 170

${ }^{16}$ Rohmanur Aziz, Dakwah Dalam Paradigma Pemberdayaan Masyarakat Muslim, dalam Jurnal Ilmu Dakwah Vol. 5 No.16 Juli-Desember 2010 , hlm.132 
dalam nilai ekonomis, melalui peningkatan pendapatan per kapita penduduk, produktivitas, pertanian, permodalan, dan kesempatan kerja yang dibarengi dengan kemampuan konsumsi masyarakat, terutama di pedesaan. Pada awalnya strategi ini dianggap efektif. Akan tetapi, karena economic oriented sementara kaidah hukum-hukum sosial dan moral terabaikan maka yang terjadi adalah sebaliknya, yakni semakin melebarnya pemisah kaya miskin terutama di daerah pedesaan. Akibatnya, begitu terjadi kreisis ekonomi maka konflik dan kerawanan sosial terjadi dimana-mana

b. The Welfare Strategy

Strategi kesejahteraan ini pada dasarnya dimaksudkan untuk memperbaiki kesejahteraan masyarakat. akan tetapi, karena tidak dibarengi dengan pembangunan kultur dan budaya mandiri dalam diri masyarakat maka yang terjadi adalah sikap ketergantungan masyarakat kepada pemerintah. Oleh karena itu, dalam setiap usaya pengembangan masyarakat, salah satu aspek yang harus diperthatikan penanganannya adalah masalah kultur budaya masyarakat. pembangunan budaya jangan sampai kontraproduktif dengan pembangunan ekonomi. Dalam konteks yang demikian inilah dakwah dengan model pengembangan masyarakat sangt relevan karena salah satu tujuannya adalah mengupayakan budaya masyarakat mandiri.

\section{c. The Responsitive Strategy}

Strategi ini merupakanreaksi terhadap strategi kesejahteraan yang dimaksudkan untuk menanggapi kebutuhan yang di rumuskan masyarakat sendiri dengan bantuan pihak luar (self need and assistance) untuk memperlancar usaha mandiri melalu pengadaan teknologi serta sumber-sumber yang sesuai bagi kebutuhan pembangunan. Akan tetapi, karena pemberdayaan masyarakat sendir belum dilakukan maka strategi yang tanggap terhadap kebutuhan masyarakat ini terlalu idealistik dan sulit ditransformasikan kepadamasyarakat. 
Satu hal yang harus diperhatikan, kecepatan teknologi sering kali bahkan selalu, tidak diimbangi dengan kesiapan masyarakat dalammenerima dan memfungsikan teknologi sendiri. Akibatnya, teknologi yang diapakai dalam penerapan strategi ini menjadi disfungsional.

\section{d. The integrated or holistic strategy}

Untuk mengatasi dilema pengembangan masyarakat karena "kegagalan" ketiga stategi seperti telah dijelaskan, maka konsep kombinasi dari unsur-unsur pokok etika stategi di atas menjadi alternatif terbaik. Stategi ini secara sistematis mengintegrasikan seluruh komponen dan unsur yang diperlukan, yakni ingin mencapai secara simultan tujuan-tujuan yang menyangkut kelangsungan pertumbuhan, persamaan, kesejahteraan dan partisipasi aktif masyarakat dalam proses pembangunan masyarakat. ${ }^{17}$

\section{HASIL DAN DISKUSI}

Dalam dunia Islam, proses pengembangan masyarakat secara eksplisit dan implisit pertama kali dilakukan oleh Nabi Muhammad Saw ketika hijrah dari Hijaz (Mekkah) ke Yatsrib (Madinah). Wujud pemberdayaan masyarakat Madinah dapat dilihat dari gerakan dakwah Nabi Muhammad Saw secara bil hal atau dakwah melalui tindakan nyata dalam memfasilitasi masyarakat Yatsrib dalam mewujudkan harapanharapannya saat itu, melakukan mediasi antara kabilah dan suku yang sedang terlibat konflik sehingga terwujud kedamaian dan mengadvokasi secara simultan dalam bentuk bimbingan dan arahan agar masyarakat Madinah hidup teratur, berkeadilan dan berpegang pada nilai-nilai luhur yang diwahyukan Alloh SWT. ${ }^{18}$

Salah satu bentuk dakwah adalah berupa tathwir Islam, sebagai upaya pemberdayaan atau pengembangan masyarakat untuk mewujudkan "khairul ummah" yang berbasis individu muslim yang berkualitas (khairul

${ }^{17}$ Moh. Ali Aziz, Rr Suhartini, A. Halim (Ed.), Dakwah Pengembangan Masyarakat: Paradigma Aksi Metodologi, Yogyakarta: LKiS Pelangi Aksara, 2009, hlm. 8-9

${ }^{18}$ Rohmanur Aziz, Dakwah Dalam Paradigma Pemberdayaan Masyarakat Muslim...hlm. 118

33 | Jurnal Bina Ummat | Vol.2 | No.2 | 2019 
bariyyah) yang dijanjikan oleh Allah akan memperoleh ridla-Nya. Tujuan ini akan dapat tercapai manakala iman, Islam dan taqwa dapat ditransformasikan menjadi tata nilai dalam kehidupan individu, kelompok, maupun institusi masyarakat, karena dengan begitu manusia diposisikan pada posisi kemanusiaannya (fitri). Dengan demikian, kegiatan dakwah merupakan proses menciptakan atau membangun tatanan sosial (kehidupan yang lebih baik) berlandaskan etika Islam, baik yang berkenaan dengan aspek (1) keyakinan, (2) fikrah; (3) sikap; dan (4) perilaku. Kemudian jika kita perhatikan hakikat dakwah dari aspek sosial, memiliki arti membangun (Tathwîr Islâm). Karena membangun itu sebagaimana biasanya dipahami sebagai suatu gerakan menciptakan kehidupan yang lebih baik bagi seluruh masyarakat. Atas dasar itu, maka dakwah dan pembangunan merupakan dua konsep yang bisa jadi berbeda, akan tetapi mempunyai titik korelasi di antara keduanya, ini berarti bahwa dakwah dalam arti luas adalah membangun, dan pembangunan merupakan proses dakwah. ${ }^{19}$

Karena memang dakwah pada hakikatnya adalah mengaktualisasikan nilai-nilai dan ajaran Islam ke dalam kehidupan seharihari, dalam lingkup pribadi, keluarga, dan masyarakat sehingga terwujudnya khairu ummah yang sejahtera lahir batin, bahagia dunia dan akhirat. Namun demikian, dakwah dalam realita kerjanya mempunyai pola-pola strategi yang beraneka warna, di antara strategi dakwah yang digunakan oleh para da'i adalah dengan dakwah pemberdayaan masyarakat. Pengembangan masyarakat bertujuan untuk mengembangkan potensi umat dari yang kurang baik menjadi baik dan lebih baik. Pengembangan tersebut juga memiliki jalannya masing-masing baik berupa pengembangan ekonomi kerakyatan, pengembangan keterampilan dan pengembangan ilmu pengetahuan sesuai dengan situasi dan kondisi masyarakat serta potensi yang dimiliki oleh seorang da'i. ${ }^{20}$

\section{Da'i Sebagai Agen Pengembangan Masyarakat}

Da'i adalah orang yang mengajak masyarakat kepada Islam sebagai pengetahuan dan pengamalan untuk tercapainya tujuan dakwah Islam itu sendiri. Dalam konteks pengembangan masyarakat, maka da'i

19 Enjang AS, Pengembangan Masyarakat Islam Dalam Sistem Dakwah, dalam Jurnal Ilmu Dakwah Vol. 5 No. 18 Edisi Juli - Desember 2011, hlm. 475

${ }^{20}$ Dedy Susanto, Pesantren Dan Dakwah Pemberdayaan Masyarakat Islam, dalam Jurnal ANNIDA, Vol. 6 No. 2, 2014, hlm. 129 
adalah penggerak, motivator dan pembimbing masyarakat untuk menjadikan masyarakat lebih baik, meningkatkan taraf hidupnya baik dalam pendidikan, ekonomi maupun sosial dan budaya.

Seorang da'i yang ingin efektif dalam pekerjaannya (pengembangan masyarakat), harus mengetahui persoalan yang dihadapi masyarakatnya. Da'i mesti memiliki rencana-rencana atau langkah-langkah yang akan ditempuh dalam upaya memecahkan masalah yang dihadapi di tengah-tengah masyarakat. Jika strategi pengembangan yang hendak diterapkan sudah ditentukan, tentu harus segera menurunkannya kepada taktik-taktik yang mungkin bisa dijalankan dalam mencapai tujuan yang hendak dicapai. ${ }^{21}$

Berikut akan dikemukakan sejumlah metode yang harus dilakukan sorang da'i dalam pengembangan masyarakat, khususnya pada masyarakat pedesaan:

a. Direct contact. Firman allah:

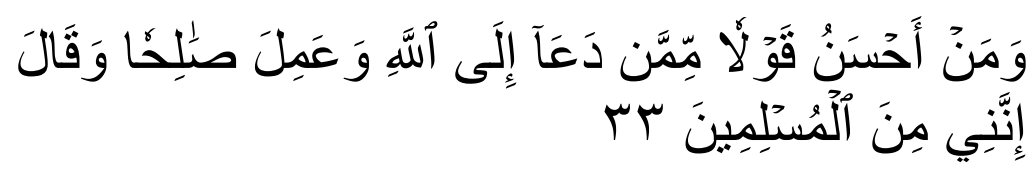

"siapakah yang lebih baik perkataannya daripada orang yang menyeru kepada Allah, mengerjakan amal yang saleh, dan berkata: "Sesunggubnya aku Termasuk orang-orang yang menyerah diri?" (Q.S. AlFushshilat:33)

Metode ini bersifat face to face relation, yang dipandang dapat merangsang minat masyarakat terhadap masalah-masalah yang dihadapi oleh masyarakat yang menjadikan mereka berpikir bahwa mereka yang harus menyelesaikan masalah mereka sendiri.

b. Demonstrasi hasil. Firman Allah:

\footnotetext{
${ }^{21}$ Nanih Machendrawaty dan Agus ahmad Safei, Pengembangan Masyarakat islam...hlm. 97
}

35 | Jurnal Bina Ummat | Vol.2 | No.2 | 2019 


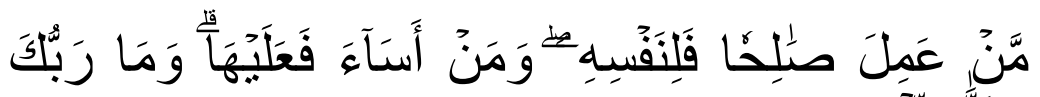

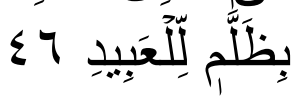

"Barangsiapa yang mengerjakan amal yang saleh Maka (pabalanya) untuk dirinya sendiri dan Barangsiapa mengerjakan perbuatan jabat, Maka (dosanya) untuk dirinya sendiri; dan sekali-kali tidaklab Rabbmu Menganiaya hamba-bambaNya.” (Q.S. Al-Fushsbilat:46)

Karena masyarakat bekerja menurut pengalamaan dan kebiasaanya mencapai hasil, maka da'i harus memahami ini dan bertugas mengubah cara kerja dan berpikir masyarakat. Dan dsinilah pentingnya strategi demonstrasi hasil diterapkan.

c. Demonstrasi proses. Firman Allah:

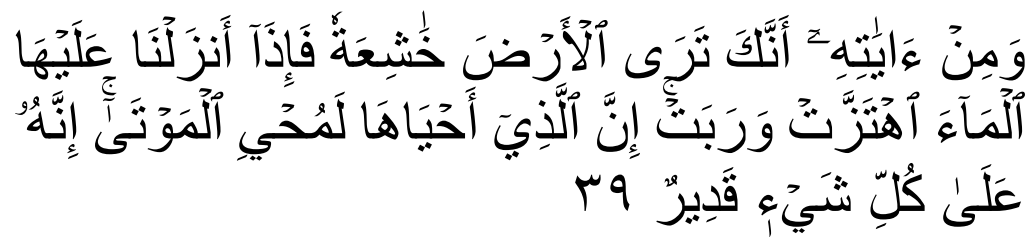

"dan di antara tanda-tanda-Nya (ialah) bahwa kau Lihat bumi kering dan gersang, Maka apabila Kami turunkan air di atasnya, niscaya ia bergerak dan subur..."(Q.S. Al-Fusbshilat:39)

Yaitu memperlihatkan kepada masyarakat bagaimana memperkembangkan suatu yang mereka kerjakan sekarang. Misalnya da'i mendemokan bagaimana membuat tempe.

d. Bekerja dengan pemimpin masyarakat. Firman Allah:

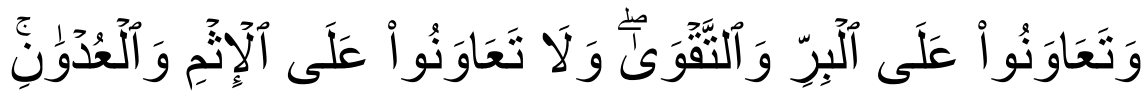

"Dan tolong-menolonglah kamu dalam (mengerjakan) kebajikan dan takwa, dan jangan tolong-menolong dalam berbuat dosa dan pelanggaran.(Q.S. Al-Maidab:2)

Bekerja sendiri tidak akan pernah bias menyamai hasil yang dicapai lewat bekerja dengan orang banyak

e. Aksi kelompok. Rasulullah bersabda: 


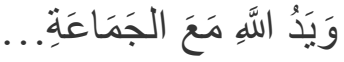

'Dan tangan Allah bersama jama'ah...( at-Tirmidæi, No.2167)

Banyak masalah yang muncul ditengah-tengah masyarakat yang hanya bisa dipecahkan melalui usaha-usaha kelompok.

f. Alat peraga. Para pengembang masyarakat dituntut mengusai berbagai macam alat peraga sebagai alat bantu. Seperti fotografi, poster, slide dll.

g. Pusat penerangan. Mendirikan pusat-pusat penerangan seperti majalah dinding, wall newspaper ditempat-tempat strategis.

h. Paksaan social. Yaitu menciptakan suatu situasi yang terpaksa orang melakukan tindakan sesuai dengan yang dikehendaki oleh seorang pengembang masyarakat. ${ }^{22}$

\section{Prinsip Dakwah Pengebangan Masyarakat}

Dakwah adalah upaya mengajak masyarakat menuju cara hidup islami dalam segala aspek kehidupan, baik aspek kerohanian, maupun aspek sosial ekonomi, politik, budaya dan hukum yang ada di masyarakat, dakwah secara etimologi adalah bentuk mashdar dari kata kerja da'a yad'u-da'watan atau du'aan yang berarti menyeru, mengajak, memanggil, mengadu, berdoa, memohon, menyuruh dan meminta. Dari seluruh makna dakwah tersebut terdapat makna komunikasi antara da'i dengan mad'u. Komunikasi tersebut dapat berbentuk ceramah, bimbingan dan juga pengembangan masyarakat. Rasulullah SAW selaku da'i dan kepala negara Madinah telah berupaya mengembangkan masyarakat kaum muslimin menuju iman dan takwa demi kebahagiaan hidup dunia dan akhirat. Pengembangan masyarakat lebih tepat menggunakan bentuk dakwah bi al-hal karena lebih menekankan aspek pelaksanaan suatu program kegiatan daripada komunikasi lisan berbentuk ceramah. Ini berarti bahwa pengemangan masyarakat berkaitan erat dengan manajemen dakwah menyangkut perencanaan, organisasi, pelaksanaan dan evaluasi kegiatan pengembangan. Prinsip pembangunan masyarakat Islam adalah holistik dan mempedulikan semua aspek kehidupan, termasuk eksistensi komponen alam bukan

\footnotetext{
${ }^{22}$ Nani Machendrawaty dan Agus ahmad Safei, Pengembangan Masyarakat islam...hlm. 98-105
}

37 | Jurnal Bina Ummat | Vol.2 | No.2 | 2019 
manusia (non human society). Pengembangan dimaksudkan sebagai upaya merubah masyarakat tradisional, miskin, terbelakang dan tidak beriman menuju masyarakat modern yang maju, kreatif, beriman dan bertakwa. ${ }^{23}$

Menurut Muhyiddin dan Safei, diperlukan metode dan strategi pengembangan dakwah agar dapat membentuk masyarakat yang harmonis dan damai. Beberapa metode dan cara yang dapat dikembangkan adalah prinsip-prinsip berikut ini:

1. Pengembangan metode bil lisan dan bil 'amal sesuai dengan tantangan dan kebutuhan.

2. Mempertimbangkan metode dan media sesuai dengan tantangan kemajuan ilmu pengetahuan dan teknologi.

3. Memilih metode dan media yang relevan, baik mimbar, panggung, media cetak, atau elektronik (radio, televisi, komputer, dan internet).

4. Mengembangkan media atau metode kultural dan struktural, yakni pranata sosial, seni, karya budaya, dan wisata alam.

5. Mempertimbangkan struktur sosial dalam tingkatan kadar intelektual, yakni khawas, awam, dan yang menentang.

6. Mempertimbangkan struktur dan tingkatan masyarakat dari segi kawasan, geografis, demografis, sosiologis, antropologis, politis, dan ekonomis.

7. Mengembangkan dan mengakomodasikan metode dan media seni budaya masyarakat setempat yang relevan, seperti wayang, drama, musik, lukisan, dan sebagainya.

8. Mempertimbangkan dan mengkaji metode pendekatan spiritual, antara lain melalui doa dan salat, silaturrahim, dan sebagainya.

9. Prinsip-prinsip pengembangan dakwah yang dipaparkan tersebut dapat digunakan sebagai pijakan untuk mengembangkan masyarakat Islam di suatu daerah dan tentu harus disesuaikan dengan kondisi masing-masing dari lokasi. ${ }^{24}$

${ }^{23}$ Ahmad Mukhlishin dan Aan Suhendri, Aplikasi Teori Sosiologi Dalam Pengembangan Masyarakat Islam, dalam Jurnal INJECT, Volume 2, No.2, Desember 2017, hlm. 223

${ }^{24}$ Ahmad Zaini, Peranan Dakwah dalam Pengembangan Masyarakat Islam .....h.hlm. 141 
Terkait dengan kajian konsep dasar strategi dakwah dalam pengembangan masyarakat yang dilanjutkan dengan merekonstrusi konsep dakwah sebagai bagian dari upaya membangun paradigma baru model dakwah pengembangan masyarakat, maka dakwah pengembangan masyarakat harus mengikuti beberapa prinsip dasar, yaitu:

Pertama, orientasi kepada kesejahteraan lahir dan batin masyarakat luas. Dakwah tidak dilaksanakan hanya sekadar memuaskan keinginan sebagian masyarakat saja. Melainkan direncanakan sebagai usaha membenahi kehidupan sosial bersama masyarakat agar penindasan, ketidakadilan, kesewenang-wenangan tidak lagi hidup di tengah-tengah mereka.

Kedua, dakwah pengembangan masyarakat pada dasarnya upaya melakukan social engineering (rekayasa sosial) untuk mendapatkan suatu perubahan tatanan kehidupan sosial yang lebih baik. Dakwah pengembangan masyarakat merupakan suatu proses perencanaan perubahan sosial yang berlandasakan nilai-nilai Islam. Sasaran untuk pengembangan masyarakat, oleh karenanya kepada setting sosial kehidupan masyarakat, daripada individu per individu. Landasan berfikir para da'i dalam melihat problem yang dihadapi masyarakat adalah sebuah permasalahan sosial, yang oleh karena itu pemecahannya juga meski dilaksanakan dalam skala kehidupan social. ${ }^{25}$

Di samping kedua prinsip dasar tersebut, ada beberapa prinsip lain yang harus terpenuhi dalam dakwah pengembanga masyarakat, yaitu:

1. Prinsip kebutuhan. Artinya, program dakwah harus didasarkan atas dan untuk memenuhi kebutuhan masyarakat. Kebtuhan di sini tidak hanya dipahami sebagai kebutuhan fisik material, tetapi juga non material. Karena itulah program dakwah perlu disusun bersama, baru kemudian dirumuskan pula metode, materi dan media dakwah. Dengan demikian, seorang da'i tidak lagi terasing dengan masyarakat sasaran dakwahnya.

2. Prinsip partisipasi. Prinsip dakwah ini menekankan pada keterlibatan masyarakat secara aktif dalam proses dakwah, mulai dari perencanaan, pengorganisasian, penggerakan penilaian dan pengembangannya. Prinsip ini antara lain bertujuan untuk: (1) Mendorong tumbuhnya perubahan sikap dan perilaku masyarakat yang kondusif untuk kemajua, (2) Meningkatkan kualitas partisipasi masyarakat, dari sekadar

${ }^{25}$ Moh. Ali Aziz, Rr Suhartini, A. Halim (Ed.), Dakwah Pengembangan Masyarakat: Paradigma Aksi Metodologi....hlm. 11 
mendukung, mengahdiri menjadi kontributor program dakwah, (3) Menyegarkan dan meningkatkan efektivitas fungsi dan peran pemimpin lokal.

3. Prinsip keterpaduan, mencerminkan adanya upaya untuk memadukan seluruh potensi dan sumber-sumber daya yang dimiliki oleh masyarakat. Dalam konteks inilah dakwah pengembangan masyarakat itu tidak monopoli sekelompok orang dan ahli, atau organisasi, tetapi lebih luas dari itu, yakni siapapun yang mempunyai komitmen community development yang perpijak kepada universalitas nilai-nilai Islam. Oleh karenanya dakwah pengembangan masyarakat itu bersifat lintas budaya dan lintas sektoral. Untuk itulah integrated or holistic strategy merupakan pilihan yang tepat dalam proses dakwah model ini.

4. Prinsip berkelanjutan. Prinsip ini menekankan, bahwa dakwah itu harus sustainanble. Artinya, dakwah itu harus berkelanjutan yang tidak dibatasi oleh waktu. Dimungkinkan, pada saatnya, para da'i itu adalah anggota masyarakat itu sendiri. Prinsip yang berkelanjutan inilah yang oleh al-qur'an disebut dengan istiqomah yang mampu menciptakan kesejahteraan dan kedamaian lahir batin. (QS. Fushilat, 41: 30).

5. Prinsip kaderisasi. Bahwa pengelolaan dan program pembangunan masyarakat hanya akan terlaksana dengan baik apabila di masyarakat tersebut terdapat atau telah disiapkan kader-kader yang berasal dari masyarakat yang memiliki sikap, pengetahuan, keterampilan dan aspirasi membangun untuk memenuhi kepentingan bersama dan untuk mempersiapkan hari depan masyarakat yang lebih baik.

6. Prinsip kemampuan sendiri menegaskan bahwa kegiatan dakwah pengembangan masyarakat itu disusun dan dilaksanakan berdasarkan kemampuan dan sumber-sumber (potensi) yang dimiliki masyarakat. Keterlibatan pihak-pihak lain, baik perorangan (da'i) maupun organisasi (lembaga-lembaga dakwah) hanyalah bersifat sementara yang berfungsi sebagai fasilitator dan trasformasi nilai keagamaan. Untuk itulah TOT (Training Of The Trainer) juru dakwah yang diambil/ direkrut dari elemen masyarakat, merupakan bagian tidak terpisahkan dari dakwah model ini. ${ }^{26}$

${ }^{26}$ Moh. Ali Aziz, Rr Suhartini, A. Halim (Ed.), Dakwah Pengembangan Masyarakat: Paradigma Aksi Metodologi... hlm. 15 


\section{Analisis Pengembangan Masyarakat Sebagai Konsep Dakwah}

Dari pemaparan sebelumnya dapat ditegaskan bahwa dakwah dan perkembangan serta kemajuan masyarakat berkaitan erat bahkan tidak dapat dipisahkan. Dakwah merupakan tuntunan dalam menata kehidupan masyarakat demi kemaslahatan dan kesejahteraan hidup di dunia dan akhirat. Secara konseptual terminologi pengertian dakwah, diarahkan pada usaha merubah sikap beragama dari masyarakat penerima dakwah dan dalam pelaksanaannya dakwah dilakukan dengan jiwa tulus serta ikhlas. Dalam al-Qur'an terdapat ayat-ayat yang menggambarkan idealisme dakwah yang bertujuan agar manusia mengikuti jalan lurus yang telah digariskan oleh Allah SWT, sehingga mereka selamat dalam kehidupan dunia dan akhirat. Hal ini juga berarti ajakan untuk merubah keadaan manusia kepada yang lebih baik, secara fisik maupun mental, sesuai dengan yang dirumuskan al-Qur'an. Di antara ayat-ayat tersebut, Allah berfirman dalam Q.S. Yusuf : 108: ${ }^{27}$

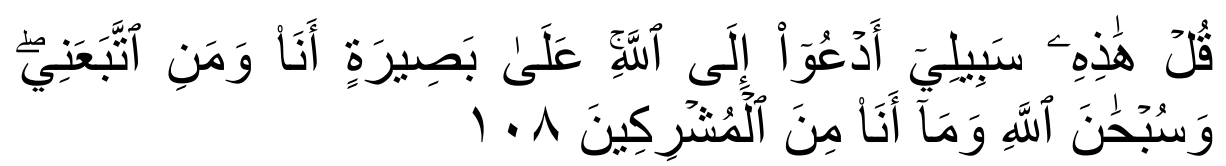

"Katakanlab: Inilah jalan (agama)ku, aku dan orang-orang yang mengikutiku mengajak. (kamu) kepada Allab dengan bujjah yang nyata, Maha Suci Allah, dan aku tiada termasuk, orang-orang yang musyrik".

Islam sebagai agama dakwah, melalui ajarannya telah memberikan solusi alternatif bagi pemecahan masalah masyarakat. Dalam pengertian immaterial, berarti dakwah sebagai aktivitas yang mampu melakukan perubahan perilaku dan pola pikir, sehingga orientasi pemikiran manusia menuju ke arah yang lebih positif. Oleh Karena itu dakwah dalam Islam adalah aktivitas yang sangat mulia yang oleh istilah alQur'an ahsanu Qaulan yakni perkataan dan perbuatan yang terbaik. (Q.S. Fushilat : 33). Dalam Islam, sasaran dakwah adalah seluruh umat manusia (masyarakat). Keberhasilan dakwah ditentukan oleh faktor-faktor yang berpengaruh, salah satu diantaranya adalah adanya lingkungan mad'u yang dikenal sebagai masyarakat. ${ }^{28}$

${ }^{27}$ Masmuddin, Dakwah Dan Pengembangan Masyarakat, dalam Jurnal Al-

Tajdid, Vol. II No. 1/Maret 2010, hlm. 39

${ }^{28}$ Ibid. hlm. 38

41 | Jurnal Bina Ummat | Vol.2 | No.2 | 2019 
Dengan demikian dapat dikatakan bahwa pengembangan masyarakat yang dilakukan seorang muslim pada dasarnya adalah kegiatan dakwah, sebuah konsep dakwah yang telah dan terus dijalankan dan diaplikasikan oleh para da'i. Hal ini disebabkan karena Islam tidak mengenal dikotomi dalam seluruh aspek kehidupannya, bahwa seluruh ajakan kepada kebaikan (menurut Al-Qur'an dan As Sunnah), peningkat taraf hidup baik dalam bidang pendidikan, ekonomi, sosial dan budaya adalah makna dari dakwah Islam itu sendiri. Sehingga dakwah yang dilakukan secara sistematis, terencana dan terukur tujuan dan proses pelaksanaanya adalah sebuah konsep pengembangan masyarakat yang idieal, dimana dakwah Islam tidak hanya memperhatikan hasil pisik tapi juga ukhrawinya, lahir dan bathinnya.

\section{KESIMPULAN}

Pengembangan masyarakat adalah usaha sistematis, terencana untuk meningkatkan dan mengembangkan kehidupan masyarakat kepada yang lebih baik, dalam bidang ekonomi, pendidikan (kesadaran dan inisiatif) dan budaya. Sedangkan dakwah dalam arti yang luas dapat dipahami sebagai usaha sadar dan terencana mengajak masyarakat kepada jalan Allah, untuk menjalankan tugasnya sebagai hamba dan khalifah di muka bumi. Sebagai hamba manusia dituntut untuk taat beribadah kepada Allah dan patuh pada perintah dan lanrangan-Nya. Sebagai Khalifah, manusia dituntut untuk mampu memenej serta mengelolah bumi ini untuk kemaslahatan dan kesejahtraanya.

Sehingga dapat ditarik kesimpulan bahwa pengembangan masayarakat adalah aplikasi dari sebagain kegiatan dakwah itu sendiri, yaitu transformasi ajaran Islam dalam bentuk amal nyata untuk mengangkat martabat masyarakat (objek dakwah) kepada yang lebih baik, berilmu, berakhlak, adil dan sejahtra. Jadi bagi seorang muslim, pengembangan masyarakat dan dakwah tidak dapat dipisahkan karena penegmabangan masyarakat adalah bagian dari gerakan besar dakwah Islam dalam mengangkat martabat sesorang atau masyarakat untuk kebahagiaannya di dunia dan akhirat.

\section{DAFTAR PUSTAKA}


Agus Riyadi, Formulasi Model Dakwah Pengembangan Masyarakat Islam, dalam Jurnal An-Nida, Vol. 6, No. 2, 2014

Ahmad Mukhlishin dan Aan Suhendri, Aplikasi Teori Sosiologi Dalam Pengembangan Masyarakat Islam, dalam Jurnal INJECT, Volume 2, No.2, Desember 2017

Ahmad Zaini, Peranan Dakwah dalam Pengembangan Masyarakat Islam, dalam Jurnal Community Development, Volume 1, Nomor 1, Juni 2016

Akmaruzzaman , Sumardjo, dan Himawan Hariyoga, Strategi Mensinergikan Program Pengembangan Masyarakat Dengan Program Pembangunan Daerah, dalam Jurnal Manajemen Pembangunan Daerah, Vol. 5 No. 1, Juni 2013

Asmuddin, Dakwah Dan Pengembangan Masyarakat, dalam Jurnal AlTajdid, Vol. II No. 1/Maret 2010

Dedy Susanto, Pesantren Dan Dakwah Pemberdayaan Masyarakat Islam, dalam Jurnal ANNIDA, Vol. 6 No. 2, 2014

Enjang AS, Pengembangan Masyarakat Islam Dalam Sistem Dakwah, dalam Jurnal Ilmu Dakwah Vol. 5 No. 18 Edisi Juli - Desember 2011

Erna, Definisi Pengembangan Masyarakat, Pendekatan Radikal Dan Pendekatan Profesional. https://www.academia.edu/

Fredian Tonny Nasdian, Pengembangan Masyarakat, Jakarta: Yayasan Pustaka Obor Indonesia, 2014

M. Djauzi Moedzakir, Teori \& Praktek Pengembangan Masyarakat Suatu Pedoman Bagi Para Praktisi, Surabaya: Usaha Nasional, 1986

Moh. Ali Aziz, Rr Suhartini, A. Halim (Ed.), Dakwah Pengembangan Masyarakat: Paradigma Aksi Metodologi, Yogyakarta: LKiS Pelangi Aksara, 2009

Nani Machendrawaty dan Agus ahmad Safei, Pengembangan Masyarakat islam, Bandung: Rosda, 2001

Rohmanur Aziz, Dakwah Dalam Paradigma Pemberdayaan Masyarakat Muslim, dalam Jurnal Ilmu Dakwah Vol. 5 No.16 Juli-Desember 2010

43 | Jurnal Bina Ummat | Vol.2 | No.2 | 2019 
Sumaryo Gitosaputro dan Kordiyana K. Rangga, Pengembangan dan Pemberdayaan Masyarakat, Konsep, Teori dan Aplikasinya di EraOtonomi Daerah, Yogyakarta: Graha Ilmu, 2015

Totok Mardikanto dan Poerwoko Soebiato, Pemberdayaan Masyarakat dalam Perspektif Kebijakan Publik, Bandung: Alfabeta, 2019

Zubaedi, Pengembangan Masyarakat: Wacana dan Praktik, Jakarta: Kencana, 2016 